\title{
MEMANFAATKAN METODE KERJA KELOMPOK DALAM MODEL DIRECT INSTRUCTION UNTUK MENGOPTIMALKAN PENINGKATAN PRESTASI BELAJAR MATEMATIKA SISWA KELAS 8 SEMESTER I TAHUN PELAJARAN 2015/2016 DI SMP NEGERI 8 BINTAN
}

\author{
Ultra Falentina \\ SMP Negeri 8 Bintan \\ e-mail: ultrafalentina2@gmail.com
}

\begin{abstract}
Mathmatics is one of the lesson which is performed on national final exam. It holds important rule to decide sudents graduation. The fact shown that many students have difficulty in this lesson. They think that mathmatics is difficult. It makes them have less interest in mathmatics. The research method used is class action research. Population of this study are 22 students of VII grade SMPN 8 Bintan. Sampling technique in this study is purposive sampling. The independent variable is group working method in direct instruction model and the dependent variable is mathmatics learning performance.The result of this research is passing grade of siclus II increasing to 85 from 72,29. It can be concluded that working method in direct instruction model can increase mathmatics learning performance of VII grade SMPN 8 Bintan.
\end{abstract}

Key Words:Working Method; Direct Instruction Model;Mathmatics Learning Performance

\begin{abstract}
Abstrak:Matematika adalah salah satu pelajaran yang dilakukan pada ujian akhir nasional. Ini memegang aturan penting untuk memutuskan sudents kelulusan. Fakta menunjukkan bahwa banyak siswa mengalami kesulitan dalam pelajaran ini. Mereka berpikir bahwa mathmatics sulit. Hal itu membuat mereka memiliki minat yang kurang di mathmatics.Metode penelitian yang digunakan adalah penelitian tindakan kelas. Populasi dari penelitian ini adalah 22 siswa kelas VII kelas SMPN 8 Bintan. Teknik pengambilan sampel dalam penelitian ini adalah purposive sampling. Variabel independen adalah metode kerja kelompok dalam model instruksi langsung dan variabel dependen adalah mathmatics kinerja belajar.Hasil penelitian ini passing grade dari siclus II meningkat menjadi 85 dari 72,29. Dapat disimpulkan bahwa metode bekerja dalam model pembelajaran langsung dapat meningkatkan mathmatics kinerja VII kelas SMPN 8 Bintan belajar.
\end{abstract}

Kata kunci: Metode Kerja Kelompok; Instruksi Model Direct; Kinerja Belajar Matematika

\section{PENDAHULUAN}

Matematika sebagai salah satu mata pelajaran yang diujikan pada Ujian Nasional memegang peranan penting sebagai salah satu penentu kelulusan siswa. Kenyataan menunjukkan bahwa mayoritas siswa merasa kesulitan dalam memahami pelajaran matematika. Mereka merasa bahwa matematika adalah pelajaran yang sulit. Sehingga sebagia siswa menunjukkan kurang berminat pada mata pelajaran ini.

Sistem Persamaan Linier Dua Variabel (SPLDV) merupakan salah satu materi pokok dalam matematika SMP kelas VIII semester I. Belajar materi ini membutuhkan pemahaman yang baik mengingat siswa dituntut untuk dapat menyelesaikan permasalahan SPLDV baik dengan cara substitusi maupun eliminasi.

Pada penelitian awal yang dilakukan di SMP Negeri 8 Bintan yang dilaksanakan pada tanggal 8 September 2015, sebanyak $60 \%$ siswa belum mencapai nilai ketuntasan. Ketidaktercapaian ketuntasan belajar ini disebabkan oleh kurang mampunya siswa dalam menyelesaikan 
permasalahan sesuai tahapan penyelesaian soal berbentuk masalah. Pola pengajaran yang selama ini dilakukan ternyata belum mampu membantu siswa dalam menyelesaikan soal-soal berbentuk masalah, mengaktifkan siswa dalam belajar, memotivasi siswa untuk menemukan ide dan pendapat mereka, dan bahkan siswa masih enggan untuk bertanya pada guru jika mereka belum paham terhadap materi yang disajikan guru.

Mengatasi kesenjangan antara harapan dengan kenyataan di lapangan, memotivasi peneliti sebagai guru kelas VIII di SMP Negeri 8 Bintan mengupayakan peningkatan prestasi belajar Matematika siswa dengan menerapkan model Direct Instruction menggunakan. Model pembelajaran langsung dipilih karena dalam pelajaran matematika materinya berupa suatu proses yang berkelanjutan dan sulit dipelajari sendiri oleh siswa sehingga perlu dipelajari secara bertahap (selangkah demi selangkah) dengan bantuan langsung dari guru. Arends (dalam Trianto,2009: 41) yang menyebutkan bahwa Model pembelajaran langsung adalah salah satu pendekatan mengajar yang dirancang khusus untuk menunjang proses belajar siswa yang berkaitan dengan pengetahuan deklaratif dan pengetahuan prosedural yang terstruktur dengan baik yang dapat diajarkan dengan pola kegiatan yang bertahap, selangkah demi selangkah. Dengan tindakan yang seperti itu diharapkan prestasi belajar peserta didik akan dapat ditingkatkan.

\section{METODE}

Dalam melaksanakan tindakan Tempat penelitian merupakan sumber diperolehnya data yang dibutuhkan dari masalah yang diteliti. Adapun tempat penelitian ini dilaksanakan di SMP Negeri 8
Bintan. Penelitian ini dilaksanakan secara bertahap dari tahap persiapan, tahap pelaksanaan, sampai tahap penyelesaian. Direncanakan dari bulan September sampai dengan Desember 2015, yaitu dengan alasan waktu ini adalah masa aktif pembelajaran sehingga memungkinkan dilakukan tindakan kelas.

Subjek penelitian tindakan ini adalah siswa-siswi kelas VIII SMP Negeri 8 Bintan tahun pelajaran 2015/2016 yang berjumlah 22 anak. Penelitian ini menggunakan Penelitian Tindakan Kelas (PTK). Menurut Rustam Mudilarto (2004). Penelitian tindakan kelas (PTK) adalah sebuah penelitian yang dilakukan oleh guru di kelasnya sendiri dengan jalan merancang, melaksanakan, dan merefleksikan tindakan secara kolaboratif dan partisipatif dengan tujuan untuk memperbaiki kinerjanya sebagai guru sehingga hasil belajar siswa dapat meningkat .

Berdasarkan dari tujuan penelitian yang ingin dicapai, penelitian ini memaparkan dan memahami dari suatu masalah berdasarkan pengamatan hasil dari latihan yang telah diberikan oleh pembimbing kepada siswanya.

Prosedur penelitian tindakan kelas ini menggunakan Model Kemmis dan Taggart. Menurut Trianto (2010: 3), model Kemmis menggunakan sistem spiral refleksi diri yang setiap siklus meliputi rencana (planning), tindakan (acting), pengamatan (observing), dan refleksi (reflecting).

Siklus dibagi dalam dua siklus, setiap siklus 1 pertemuan, setiap putaran dilakukan dua tindakan yaitu tindakan 1 dan 2 dimana masing-masing putaran dikenai perlakuan yang sama (alur kegiatan yang sama) dan membahas satu sub pokok bahasan yang diakhiri dengan tes formatif (post tes) pada akhir setiap siklus. Dibuat dalam satu pertemuan dalam 1 siklus, 
dimaksudkan untuk memperbaiki sistem pengajaran yang telah dilaksanakan. Penelitian tindakan kelas ini bertujuan untuk menyelesaikan masalah yang berhubungan dengan kesulitan siswa dalam memahami konsep Sistem Persamaan Linier Dua Variabel (SPLDV).

\section{HASIL DAN PEMBAHASAN}

\section{A. Hasil Penelitian}

\section{Siklus I}

a. Perencanaan

Siklus pertama direncanakan dengan 2 kali tindakan. Tindakan 1-2 masingmasing memerlukan 2 jam pelajaran $(2 \mathrm{x}$ 40 menit).

Dua tindakan dalam penelitian ini adalah:

1) Tindakan I: Penjelasan materi Sistem Persamaan Linier Dua Variabe (SPLDV) secara garis besar, serta pelaksanaan model direct instructionsampai pada kelompok,

2) Tindakan II: Pelaksanaan model direct instruction, serta pemberian soal kuis, presentasi dari setiap kelompok, mengerjakan soal evaluasi siklus 1 .

b. Pelaksanaan Tindakan

Siklus I dilaksanakan selama $4 \times 40$ menit (2 kali pertemuan) yaitu pada hari Senin 28 Mei, dan Selasa 23 Nopember 2015. Peneliti merencanakan 2 kali pertemuan untuk siklus I ini dengan alasan subjek penelitian, dalam hal ini adalahsiswa kelas VIII belum efektif berjalan model pembelajaran yang diterapkan sehingga dalam pelaksaan tindakannya pun belum bisa berjalan secara sempurna.

c. Observasi

Hasil observasi menunjukan bahwa secara umum kegiatan siswa sudah sesuai dengan yang diharapkan, sebagian besar indikator dan deskriptor pengamatan muncul dalam kegiatan siswa. Jumlah nilai pengamat I adalah 46, dan jumlah skor nilai pengamat II adalah 47, sedangkan maksimal adalah 60 .

Sehingga nilai rata-ratanya adalah: $\frac{46+47}{2}=46,5$

Jadi nilai aktivitas siswa adalah: $\frac{46,5}{60} \times 100 \%=77,5 \%$

Maka taraf keberhasilan siswa pada taraf Baik

d. Hasil Catatan Lapagan

Hasil catatan lapangan pada siklus I yaitu:

1. Masih banyak siswa yang terlihat diam ketika guru memberi penjelasan

2. Suasana kelas agak ramai saat siswa sedang melakukan belajar dalam kelompok.

3. Siswa masih memilih-milih teman ketika kelompok belajar sudah terbentuk

4. Ada beberapa siswa yang kurang aktif belajar dalam kelompok

5. Siswa masih belum terbiasa belajar model direct instruction.

6. Dalam mengerjakan soal kuis maupun tes evaluasi masih ada siswa yang contekan karena mereka kurang percaya diri pada kemampuannya.

e. Hasil Tes

Berikut hasil penilaian pada siklus I:

Tabel 1 Prestasi Belajar Siklus 1

\begin{tabular}{cccc}
\hline \multirow{2}{*}{ No } & \multirow{2}{*}{$\begin{array}{c}\text { Prestasi } \\
\text { Belajar }\end{array}$} & \multicolumn{2}{c}{ Jumlah } \\
\cline { 3 - 4 } & Tuntas & 9 & $\%$ \\
\hline 2 & Tidak Tuntas & 13 & 59,90 \\
\hline & Jumlah & 22 & 100
\end{tabular}

c. Refleksi

Prestasi belajar siswa berdasarkan hasil tes siklus I menunjukkan bahwa prestasi 
belajar siswa belum bisa memenuhi ketuntasan belajar yang diharapkan. Siswa kurang aktif menyampaikan pendapat dalam diskusi kelompok, serta dalam menyelesaikan soal kuis maupun tes evaluasi masih ada siswa yang contekan dengan temannya.

\section{Siklus II}

a. Perencanaan

Siklus kedua ini direncanakan dengan $2 \mathrm{x}$ tindakan. Tindakan 1, dan 2, masingmasing memerlukan waktu 2 jam pelajaran ( 2 x 30 menit).

Dua tindakan dalam penelitian ini adalah:

1) Tindakan I: Penjelasan materi SPLDV metode eliminasi, SPLDV subsitusi, SPLDV campuransecara garis besar, serta pelaksanaan model direct instruction samapai pada kelompok

2) Tindakan II: Pelaksanaan model direct instruction, serta pemberian soal kuis, pelaksanaan evaluasi siklus II

b. Pelaksanaan Tindakan.

Pada siklus II ini dilaksanakan pada hari Senin, 7 Desember 2015 dan Kamis, 10 Desember 2015. Peneliti merencanakan 2 kali pertemuan. Pada awal pertemuan ke-I ( 5 menit) peneliti memulai pelajaran dengan salam yang dijawab serempak oleh siswa. Selanjutnya peneliti mengabsen dan menyampaikan tujuan pembelajaran yang ingin dicapai, yaitu dapat menjelaskan apa yang dimaksud dengan SPLDV metode eliminasi, SPLDV subsitusi, SPLDV campuran.

Pada pertemuan inti (70 menit) siswa masih duduk di tempat duduk masingmasing karena siswa belum belajar kelompok, kegiatan peneliti selanjutnya adalah menjelaskan materi SPLDV metode eliminasi, SPLDV subsitusi, SPLDV campuran secara garis besar saja (klasikal) selama 20 menit.

Kemudian pertemuan ini dilanjutkan siswa berkumpul dalam kelompok masing-masing selama (25 menit), dan peneliti menyuruh anggota kelompok untuk memilih ketua kelompok yang baru.

Pada tahap akhir (5 menit) Di akhir pembelajaran (5 menit), sbelum diakhiri peneliti, peneliti bersama-sama dengan siswa membuat kesimpulan sementara tentang materi yang baru saja dipelajari yaitu tentang materi Sistem Persamaan Linier Dua Variabel (SPLDV). Kemudian menginformasikan bahwa pada pertemuan kedua selain akan melanjutkan diskusi dan presentasi kelompok juga akan diadakan tes individu (post tes).

Pada pertemuan ke-II 5 menit) sebelumnya, peneliti membuka pelajaran dengan mengucapkan salam yang dijawab serempak oleh siswa, memeriksa daftar hadir dan memotivasi belajar siswa. Sesuai dengan rencana pada hari sebelumnya bahwa hari ini akan diadakan diskusi kelompok asal, maka peneliti dibantu teman sejawat dan Guru Matematika mengatur posisi tempat duduk sesuai jumlah kelompok yang sudah dibentuk sebelumnya.

Pada tahap inti (70 menit) setelah siswa berkumpul dengan kelompok masing-masing, maka peneliti menyuruh 2 kelompok yang belum presentasi diberi waktu 15 menit, maka mereka mempersiapkan satu anak sebagai perwakilan tiap kelompok untuk mempresentasikan materi.

Kegiatan pos tes (50 menit) segera bisa dilaksanakan karena posisi siswa 
sudah berada dalam tempat duduk masing-masing sesuai permintaan peneliti pada akhir pertemuan I. Penelit pada kegiatan ini akan memberikan tes akhir (post tes) pada akhir siklus II. Setelah selesai pengumuman peneliti membagikan soal tes pada masingmasing siswa dan mengamati jalannya kegiatan.

Semua siswa mengumpulkan hasil jawaban mereka, dan waktu masih sisa 10 menit kemudian peneliti memberikan angket kepada siswa. Dan setelah selesai mengisi angket maka seluruh siswa mengumpulkan ke depan. Selanjutnya pembelajaran diakhiri.

\section{c. Observasi}

Secara umum kegiatan siswa sudah sesuai dengan yang diharapkan, sebagian besar indikator dan deskriptor pengamatan muncul dalam kegiatan siswa. Jumlah nilai pengamat I adalah 55, dan jumlah skor nilai pengamat II adalah 56, sedangkan maksimal adalah 60 .

Sehingga nilai rata-ratanya adalah: $\frac{52+54}{2}=53$

Jadi nilai aktivitas siswa adalah: $\frac{53}{60} \times 100 \%=88 \%$

Maka taraf keberhasilan siswa pada taraf Sangat Baik.

d. Hasil Wawancara

Berdasarkan hasil wawancara yang dilakukan peneliti, dapat disimpulkan bahwa siswa merasa senang dengan model direct instruction, karena mereka dapat saling bertukar pikiran untuk memecahkan sustu permasalahan yang dihadapi secara besama-sama, saling bantu-membantu dan dilakukan tanpa membedakan jenis kelamin dan kemapuan siswa, sehingga mereka lebih mudah dalam memahami materi yang disampaikan.

e. Hasil Angket Siswa

Pada penghitungan skor rata-rata pada angket respon siswa menunjukkan bahwa hasil angket respon siswa semua siswa bersifat positif.

f. Hasil Catatan Lapangan

1. Siswa kelihatan tampak serius memperhatikan penjelasan materi yang disampaikan oleh guru dan sudah berani mengajukan pendapat dan pertanyaan jika belum faham

2. Suasana kelas agak ramai tetapi masih tetap dalam situasi kondusif

3. Siswa terlihat sudah aktif dan tidak ragu-ragu lagi dalam menyampaikan pendapat

4. Siswa merasa sangat senang belajar dalam kelompok model direct instruction

5. Siswa sudah tidak ada yang bercanda lagi dengan teman saat belajar kelompok berlangsung

6. Siswa sudah terbiasa dengan temanteman satu kelompok

7. Siswa dapat mengerjakan soal kuis maupun post tes siklus II. Sudah tidak ada contekan karena kepercayan dan kemapuan diri sudah meningkat

g. Hasil Tes Siklus II

Berikut adalah hasil penilaian pada siklus II:

Tabel 2 Prestasi Belajar Siklus I1

\begin{tabular}{cccc}
\hline No & $\begin{array}{c}\text { Prestasi } \\
\text { Belajar }\end{array}$ & \multicolumn{2}{c}{ Jumlah } \\
\cline { 3 - 4 } & Tuntas & 20 & $\%$ \\
\hline 1 & Tun & 90,9 \\
\hline 2 & Tidak Tuntas & 2 & 9,00 \\
\hline & Jumlah & 22 & 100
\end{tabular}

\section{h. Refleksi}

Secara umum pada siklus II sudah menunjukkan adanya peningkatan 
partisipasi aktif dari siswa dan adanya peningkatan prestasi belajar bagi siswa serta keberhasilan guru/peneliti dalam menggunakan pendekatan model direct instruction. Oleh karena itu tidak perlu dilanjutkan pada siklus berikutnya dan tahap penelitian berikutnya adalah penulisan laporan.

\section{B. Pembahasan Hasil Penelitian}

Pada pelaksanaan siklus I dan siklus II memberikan perbaikan yang positif dalam diri siswa. Hal tersebut dibuktikan dengan keaktifan siswa dalam mengikuti pembelajaran matematika di kelas, misalnya siswa yang semula pasif dalam belajar kelompok sudah menjadi aktif dan siswa dalam menyelesaikan soal tes tidak ada lagi yang contekan dengan temannya karena siswa sudah yakin dengan kemampuannya sendiri.

Berdasarkan keaktifan siswa dalam kegiatan yang telah dilakukan menun jukkan adanya peningkatan dari tiap tindakan. Perubahan positif pada keaktifan siswa berdampak pula pada prestasi belajar dan ketuntasan belajar.

Tabel 3. Peningkatan Prestasi

\begin{tabular}{lccc}
\hline \multicolumn{1}{c}{ Kriteria } & Siklus I & $\begin{array}{c}\text { Siklus } \\
\text { II }\end{array}$ & $\begin{array}{c}\text { Pening } \\
\text { katan }\end{array}$ \\
\hline $\begin{array}{l}\text { Rata-rata } \\
\text { hasil belajar } \\
\text { siswa }\end{array}$ & 72,59 & 85 & 12,41 \\
\hline $\begin{array}{l}\text { Ketuntasan } \\
\text { belajar siswa }\end{array}$ & $40,9 \%$ & $90,9 \%$ & $50 \%$ \\
\hline
\end{tabular}

Dari tabel di atas dapat diketahui bahwa ada peningkatan yang signifikan pada rata-rata hasil belajar siswa dari Siklus I ke siklus II, yaitu sebesar 12,41 begitu pula pada ketuntasan belajar matematika terjadi peningkatan sebesar $50 \%$ dari siklus I ke siklus II. Dengan demikian pada siklus II telah mencapai target awal bahwa model direct instruction mampu meningkatkan hasil prestasi belajar matematika. Hal ini sesuai dengan pendapat Edward, bahwa " model direct instruction telah unggul dalam meningkatkan hasil akademik bila dibandingkan dengan pengalaman belajar individu/kompetitif'. Karena kelompok yang terdiri dari dari lima orang terbukti sangat efektif. Sedangkan Sudjana mengemukakan, beberapa siswa dihimpun dalam satu kelompok dapat terdiri dari 4-6 orang siswa. Jumlah yang paling tepat menurut hasil penelitian Slavin adalah hal itu dikarenakan kelompok yang beranggotakan 4-6 orang siswa lebih sepaham dalam menyelesaikan suatu permasalahan dibandingkan dengan kelompok yang beranggotakan 2-4 orang (Isjoni, 2007: $55)$.

\section{SIMPULAN}

Berdasarkan uraian diatas dapat disimpulkan bahwa:

1. Penerapan Model direct instruction dapat meningkatkan hasil prestasi belajar siswa pada pokok bahasan Sistem Persamaan Linier Dua Variabe (SPLDV)

2. Ada peningkatan yang signifikan pada rata-rata hasil belajar siswa dari Siklus I ke siklus II, yaitu sebesar 12,41. Hal ini menunjukkan bahwa pada siklus I ketuntasan belajar siswa belum tercapai yaitu sebesar 72,59, sedangkan pada siklus II meningkat menjadi 85 yang sudah memenuhi kriteria ketuntasan minimum (KKM) 75 dan ketuntasan belajar siswa 85, pada siklus II menunjukkan peningkatan sebesar 12,41. Dengan demikian pada siklus II telah mencapai target, bahwa model direct instruction mampu meningkatkan prestasi belajar matematika.

3. Siswa menunjukkan respon yang positif terhadap model direct instruction. 


\section{DAFTAR PUSTAKA}

Syaiful, Bahri,Djamarah, 2010, Strategi Belajar Mengajar, Jakarta:Rineka Cipta.

Suharsimi,Arikunto,1992, ProsedurPenelitianSuatu PendekatanPraktek, Jakarta:RinekaCipta.

Suharsimi, Arikunto, 2006, Prosedur Penelitian Suatu Pendekatan Praktik, Jakarta: PT Rineka Cipta
Suharsimi,Arikunto, $\mathrm{kk}, 2006$, PenelitianTindakanKelas, Jakarta: BumiAksara

Trianto, 2007, model-model Pembelajaran Inovative Berorientasi Kontruktivistik, Jakarat: Prestasi Pustaka Publiser.

Trianto, 2010, Panduan Lengkap Penelitian Tindakan Kelas,Surabaya:Prestasi Pustakaraya. 